\title{
IN PURSUIT OF ARCHITECTURE FICTION
}

\author{
Kazys Varnelis \\ The Network Architecture Lab, Graduate School of Architecture, \\ Planning and Preservation, Columbia University, \\ 1172 Amsterdam Avenue, New York, New York 10027 \\ E-mail:kazys@varnelis.net \\ Submitted 9 Dec. 2010
}

\begin{abstract}
This essay examines the role of architecture fiction and ecstatic realism as strategies for architects working within a protracted period of economic collapse. It reviews the history of the concept of architecture fiction and explores Werner Herzog's idea of ecstatic realism as a means of understanding what the possibilities are for the interaction of art and architecture. Through a series of examples, I explore the development of innovative ways of interpreting the world.
\end{abstract}

Keywords: fiction, ecstatic realism, innovative strategies, Werner Herzog, crisis, rethinking of architecture.

In this essay, I want to pursue the emerging concept of "architecture fiction". Developed by science fiction novelist Bruce Sterling and elaborated in a conversation between Sterling and myself on the Internet, architecture fiction identifies a new kind of interaction between architecture and the arts in which architects transgress into the territory of the novelist to themselves envision alternate realities and shape narratives (Sterling 2006; Varnelis 2009).

At the outset, I want to acknowledge that this project may appear anachronistic. After all, in Victor Hugo's Notre Dame de Paris, the novelist puts the following words in the mouth of Archdeacon Don Claude Frollo: "This will kill that...small things come at the end of great things; a tooth triumphs over a body. The Nile rat kills the crocodile, the swordfish kills the whale, the book will kill the building!" (Hugo 1978). There is no question that as a dominant producer of social meaning and order, the book did kill the edifice. By the time that Hugo was writing the Protestant injunction to read the Bible instead of the iconic stories of sculptures and paintings in the cathedral had teamed with growing mass literacy and cheap publishing to make the book the foremost means of cultural commu- nication. Containing greater density of information, books had the capacity to make legible conditions in ways that buildings could not and had the ability to be circulated more widely. Take the case of Lithuania, for example, where the national revival took place through the book and the recovery of the Lithuanian language, not through architecture. The book had taken over from the building.

With the advent of postmodernity in the last quarter of the twentieth century, both book and building started to take on new qualities. Refigured within the broader realm of media, the book began to lose its distinct boundaries from capital. On the one hand, culture permeated capital - its techniques becoming central to marketing in an era of post-Fordist flexible accumulation - on the other hand, capital colonized culture, formerly an outpost of resistance to the rationalizing and banalizing forces of the economic. The result was that in the West, the study of literature in university became more likely a route into a career in advertising or television-script writing as it was a marker legitimating class taste. Art, in turn, became matter of investment. But, above all, architecture was the signal art of postmodernism, its enthusiastic eclecticism pointing 
the way for postmodernity, rejecting function and production for form and culture (Jameson 1991). More than any other art form, postmodern architecture represented capital refiguring itself as "creative". By the late 1980s financiers had replaced artists in the lofts of Manhattan's Soho district, a moment epitomized in the book and film American Psycho, where the murderous Patrick Bateman understands himself as an artist, a clone of Gordon Matta-Clark only instead of turning his chainsaw to working-class suburban homes butchering companies and employees in the process of mergers and acquisitions during the day while dismembering attractive young women at night with a chainsaw. With the dot.com boom, capitalism depicted itself as ever more creative, ever more wrapped up in media. Capital and information began to lose their distinction and, in the media at least, the bourgeoisie refigured itself as the "creative class", innovative, knowledge-based, and independent players (Florida 2002).

With the collapse of the lightest form of capital - the dot.com boom - creative capitalists turned back to the heaviest form of capital - building - employing esoteric fictional techniques to write financial instruments that permitted buildings to be parceled up and circulated across the world, traded as if they were nothing more than bits of information. In doing so, capital departed from any kind of logical basis for return on investment. The creative economy was the furthest epitome of this kind of economic fiction. The inexorable efficiencies of the Internet and the economic collapse caused by excess accumulation and profit-seeking now leave both architecture and the media undone. Our century is the turning point, in terms of economic and environmental sustainability. Profit rates in manufacturing have been declining since the 1960s. In most advanced societies - the EU (and by this of course Lithuania too), the US, Japan - the middle class is history. We are likely entering into a long period that Gopal Balakrishnan has called a "stationary state" in which growth is minimal and capitalism struggles even as alternatives do not clearly emerge. As Balakrishnan points out, Adam Smith himself never expected the wealth of nations to improve perpetually but rather expected it would come to as resources were exhausted and productivity declined (Balakrishnan 2009).

Rethinking architecture under these circumstances is crucial. To be fair, the financialization of architecture makes any architecture fiction we come up with seem preposterously timid. How could we imagine the baffling monsters that capital produced such as credit default swaps, collateralized debt obligations, or the ubiquitous and tragic, slightly-radioactive granite countertops the color of country paté? Instead of pes- simism, however, I would like to suggest it is possible, even necessary, for architects to do something besides build in the most traditional sense. If architectural education is, generally speaking, tied to ideas developed during the boom, we need to rethink this condition, to develop new tasks for architects in the stationary state.

As Pedro Gadanhohas suggested to me, architecture fiction is a necessary corrective to the accelerating immateriality and fictional nature of architecture itself (personal e-mail... 2010). Indeed, it is a way of fighting that condition, of imagining alternatives to the fictions that capital has written for us. Architecture fiction serves as a means of making architects pause and pull back from the thoughtless building that consumed the field during the last boom.

But architecture fiction is not new. It's an ancient tradition that has kept architecture flourishing in times in which architects could not build or thought it improper to build. Take the Carceri or Campo Marzio of Giovanni Battista Piranesi, which clearly represents the operations of architecture fiction in the eighteenth century. More recently, science fiction cinema has become more and more a matter of creating compelling environments that play a key role as actors in the narrative. Whether it be Solaris, 2001: A Space Odyssey, Blade Runner, Thirteen Monkeys, Star Wars, Minority Report or Inception, architecture fiction is a key part of the cinematic imaginary today. Moreover, with the rise of computer-generated animation in cinema, young graduates of architecture schools have wound up working on such films, closing the circle between architecture fiction and contemporary cinema.

To close this paper, I'd like to point in two directions - atemporality (itself another concept that I have developed with Sterling) and Werner Herzog's idea of "ecstatic realism". Our architecture fiction needs to respond to its time and to work with the sorts of narrative structures that are native to network culture. To understand atemporality, take Chris Nolan's recent film Inception. Clearly the film evokes an unspeakably powerful new technology. At the same time, there are no traces on contemporary technology in this film or any other signs that would put this film in a distinct time period. There is a bullet train and the actors dress in clothes that any of us could wear, but it could be any time since 1990. The environments constructed within the film (itself a reflection on and even manual for the construction of architecture fiction) were intentionally banal formally, if exceedingly complex - even impossible - from a performative aspect. Even as it complicates any idea of temporality throughout, the film studiously 
avoids grounding itself in any identifiable temporality, thus responding to the condition that Jean Baudrillard describes of the end of history ended at the millennium (Baudrillard 1994, 1997). Similarly, we can see such work in the postcards of Arūnas Gudaitis that depicting the contemporary of Vilnius using the colors and framing techniques of postcards from the 1980s.

Ecstatic realism points to another twist in recent cinema and fiction in which the documentary becomes a matter for fiction. Perhaps the supreme master of this genre, Werner Herzog writes.

Our entire sense of reality has been called into question. But I do not want to dwell on this fact any longer, since what moves me has never been reality, but a question that lies behind it [beyond; dahinter]: the question of truth. Sometimes facts so exceed our expectations have such an unusual, bizarre power - that they seem unbelievable. But in the fine arts, in music, literature, and cinema, it is possible to reach a deeper stratum of truth - a poetic, ecstatic truth, which is mysterious and can only be grasped with effort; one attains it through vision, style, and craft. In this context I see the quotation from Blaise Pascal about the collapse of the stellar universe not as a fake ["counterfeit"; Fälschung], but as a means of making possible an ecstatic experience of inner, deeper truth (Herzog 2010).

In the work of Werner Herzog or for that matter the writing of David Foster Wallace, such ecstatic realism suggests that if the bounds of what is real and what is counterfeit are undone, then the real is as much a topic for architecture fiction as are its boldest inventions.

\section{References}

Balakrishnan, G. 2009. Speculations on the Stationary State, The New Left Review 59: 5-26.

Baudrillard, J. 1997. The End of the Millennium or the Countdown, Economy \& Society 26(4): 447-55. doi:10.1080/03085149700000023

Baudrillard, J. 1994. The Illusion of the End. Stanford, CA: Stanford University Press.

Florida, R. L. 2002. The Rise of the Creative Class: And How It's Transforming Work, Leisure, Community and Everyday Life. New York, NY: Basic Books.

Jameson, F. 1991. Postmodernism, or, the Cultural Logic of Late Capitalism, Post-Contemporary Interventions. Durham: Duke University Press.

Herzog, W. 2010. On the Absolute, the Sublime, and Ecstatic Truth, trans. Moira Weigel, Arion 17(3). Available from Internet: $<$ http://www.bu.edu/arion/on-the-absolute-thesublime-and-ecstatic-truth/>.

Hugo, V. 1978. Notre Dame of Paris, trans. John Sturrock. New York: Penguin. 188 p.

Personal e-mail from Pedro Gadanho to author, July 24, 2010.
Sterling, B. 2006. Science Fiction and Architecture Fiction, Off Center: Outside Ideas from the Walker, March 3. Available from Internet: <http://blogs.walkerart.org/ offcenter/2006/03/20/science-fiction-and-architecturefiction/>.

Varnelis, K. 2009. In Defense of Architecture (Fiction), varnelis.net, March 2. Available from Internet: $<$ http://varnelis. net/blog/in_defense_of_architecture_fiction $>$.

\section{SIEKIANT ARCHITEKTŪROS FIKCIJOS}

\section{K. Varnelis}

Santrauka. Straipsnyje nagrinejjama architektūros fikcija ir ekstatinis realizmas. Daroma prielaida, kad tai yra strategijos, taikytinos architektūros kūryboje užsitęsusios ekonominès griūties laikotarpiu. Apžvelgiama architektūros fikcijos koncepcijos raida ir tiriama Wernerio Herzogo ekstatinio realizmo ideja kaip atverianti naujas architektūros ir dailès sąveikos galimybes. Pasitelkiant ịvairių meno sričių pavyzdžius atskleidžiami inovatyvūs šiu dienụ pasaulio ir architektūros prasmès jame interpretavimo būdai.

Reikšminiai žodžiai: fikcija, ekstatinis realizmas, architektūros permąstymas, Werner Herzog, krizè, inovatyvios strategijos.

\section{KAZYS VARNELIS}

Son of the artist of the same name, is Director of the Network Architecture Lab at Columbia University and co-founder of the conceptual architecture group AUDC, which published Blue Monday in 2007. Other books he has edited include Networked Publics and The Infrastructural City and focus on recent changes in telecommunications and demographics on cities and contemporary culture. He is currently producing The New City Reader with Joseph Grima for the Last Newspaper exhibit at the New Museum. His forthcoming book is titled Life after Networks: A Critical History of Network Culture. 